\title{
Community-Scale Attic Retrofit and Home Energy Upgrade Data Mining
}

M. Berman, P. Smith, and J. Jackson Alliance for Residential Building Innovation

May 2015 


\section{NOTICE}

This report was prepared as an account of work sponsored by an agency of the United States government. Neither the United States government nor any agency thereof, nor any of their employees, subcontractors, or affiliated partners makes any warranty, express or implied, or assumes any legal liability or responsibility for the accuracy, completeness, or usefulness of any information, apparatus, product, or process disclosed, or represents that its use would not infringe privately owned rights. Reference herein to any specific commercial product, process, or service by trade name, trademark, manufacturer, or otherwise does not necessarily constitute or imply its endorsement, recommendation, or favoring by the United States government or any agency thereof. The views and opinions of authors expressed herein do not necessarily state or reflect those of the United States government or any agency thereof.

Available electronically at http://www.osti.gov/bridge

Available for a processing fee to U.S. Department of Energy and its contractors, in paper, from:

U.S. Department of Energy Office of Scientific and Technical Information

P.O. Box 62

Oak Ridge, TN 37831-0062

phone: 865.576 .8401

fax: 865.576 .5728

email: mailto:reports@adonis.osti.gov

Available for sale to the public, in paper, from:

U.S. Department of Commerce

National Technical Information Service

5285 Port Royal Road

Springfield, VA 22161

phone: 800.553 .6847

fax: 703.605.6900

email: orders@ntis.fedworld.gov

online ordering: http://www.ntis.gov/ordering.htm 


\title{
Community-Scale Attic Retrofit and Home Energy Upgrade Data Mining
}

\author{
Prepared for: \\ The National Renewable Energy Laboratory \\ On behalf of the U.S. Department of Energy's Building America Program \\ Office of Energy Efficiency and Renewable Energy \\ 15013 Denver West Parkway \\ Golden, CO 80401 \\ NREL Contract No. DE-AC36-08GO28308 \\ Prepared by: \\ M. Berman, P. Smith, and J. Jackson \\ Alliance for Residential Building Innovation \\ Davis Energy Group \\ 123 C Street \\ Davis, CA 95616 \\ NREL Technical Monitor: Michael Gestwick \\ Prepared under Subcontract No. KNDJ-0-40340-04
}

May 2015 
The work presented in this report does not represent performance of any product relative to regulated minimum efficiency requirements.

The laboratory and/or field sites used for this work are not certified rating test facilities. The conditions and methods under which products were characterized for this work differ from standard rating conditions, as described.

Because the methods and conditions differ, the reported results are not comparable to rated product performance and should only be used to estimate performance under the measured conditions. 


\section{Contents}

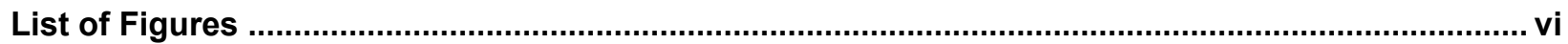

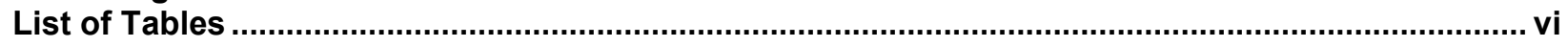

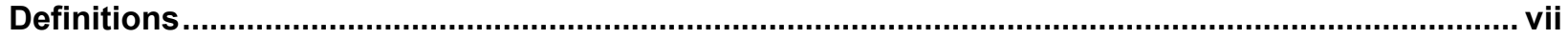

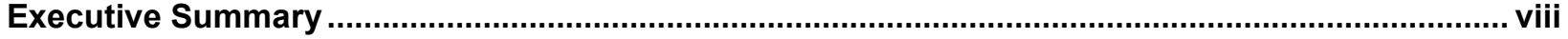

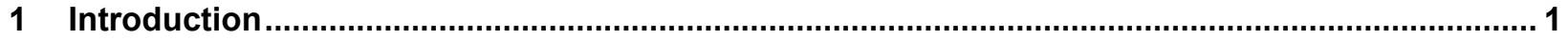

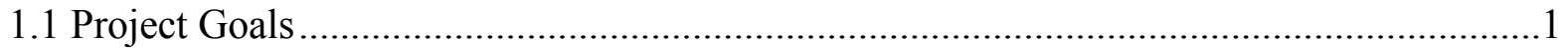

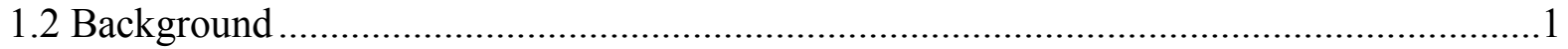

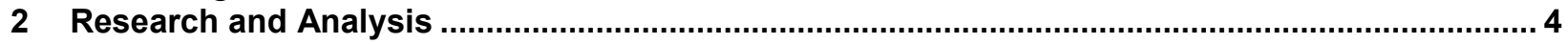

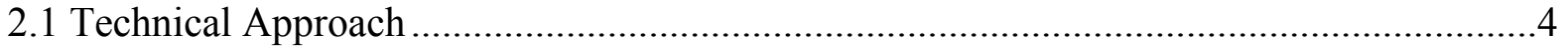

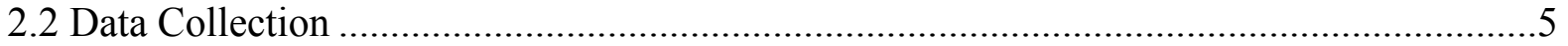

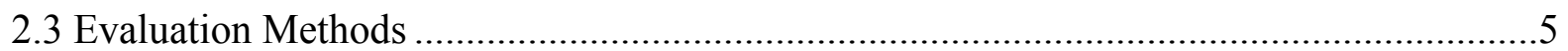

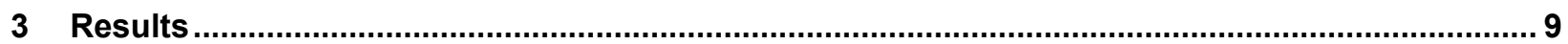

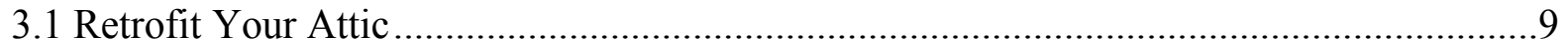

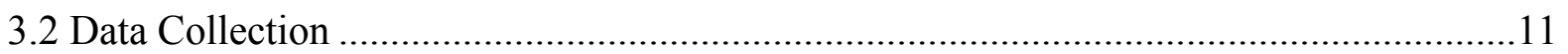

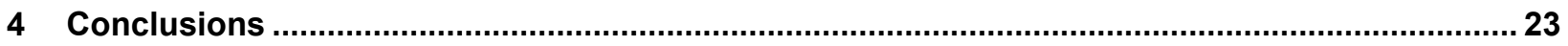

Bibliography .......................................................................................... Error! Bookmark not defined. 


\section{List of Figures}

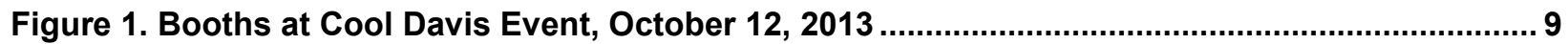

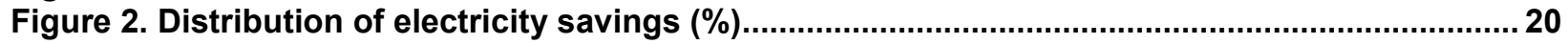

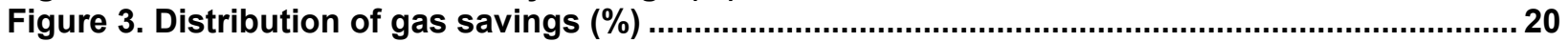

Figure 4. Space cooling savings as a function of efficiency measures implemented ....................21

Figure 5. Space heating savings as a function of efficiency measures implemented ..................... 21

Unless otherwise noted, all figures were created by the ARBI team.

\section{List of Tables}

Table 1. Volunteer Door-to-Door Outreach Results ............................................................................ 10

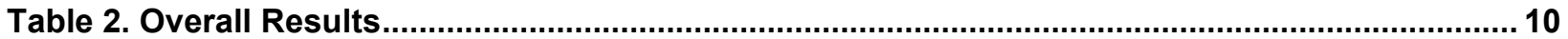

Table 3. HEU Measures Installed in 31 Hot-Dry Climate Residences ............................................. 13

Table 4. Total Electricity and Natural Gas Savings From the HEUs ............................................17

Table 5. Air-Conditioning Electricity Savings From the HEUs ..................................................... 18

Table 6. Natural Gas Baseload and Space Heating Savings From the HEUs ................................... 19

Unless otherwise noted, all tables were created by the ARBI team. 


\section{Definitions}

$\begin{array}{ll}\text { ARBI } & \text { Alliance for Residential Building Innovation } \\ \text { BAFDR } & \text { Building America Field Data Repository } \\ \text { BEopt }^{\mathrm{TM}} & \text { Building Energy Optimization Software } \\ \text { CDD } & \text { Cooling Degree Day } \\ \text { CDI } & \text { Cool Davis Initiative } \\ \text { DEG } & \text { Davis Energy Group } \\ \text { HDD } & \text { Heating Degree Day } \\ \text { HEA } & \text { Home Energy Assessment } \\ \text { HEU } & \text { Home Energy Upgrade or Retrofit } \\ \text { HVAC } & \text { Heating, Ventilating, and Air Conditioning } \\ \text { PG\&E } & \text { Pacific Gas \& Electric Company } \\ \text { RYA } & \text { Retrofit Your Attic } \\ \text { TMY } & \text { Typical Meteorological Year }\end{array}$




\section{Executive Summary}

Retrofitting is an essential element of any comprehensive strategy for improving residential energy efficiency. The residential retrofit market is still developing, and program managers must develop innovative strategies to increase uptake and promote economies of scale. Residential retrofitting remains a challenging proposition to sell to homeowners, because awareness levels are low and financial incentives are lacking.

The U.S. Department of Energy's Building America research team, Alliance for Residential Building Innovation (ARBI), implemented a project to increase residential retrofits in Davis, California. The project used a neighborhood-focused strategy for implementation and a low-cost retrofit program that focused on upgraded attic insulation and duct sealing. ARBI worked with a community partner, the not-for-profit Cool Davis Initiative, as well as selected area contractors to implement a strategy that sought to capitalize on the strong local expertise of partners and the unique aspects of the Davis, California, community. Working with community partners also allowed ARBI to collect and analyze data about effective messaging tactics for community-based retrofit programs.

ARBI expected this project, called Retrofit Your Attic, to achieve higher uptake than other retrofit projects, because it emphasized a low-cost, one-measure retrofit program. However, this was not the case. The program used a strategy that focused on attics - including air sealing, duct sealing, and attic insulation - as a low-cost entry for homeowners to complete home retrofits. The price was kept below $\$ 4,000$ after incentives; both contractors in the program offered the same price. The program completed only five retrofits. Interestingly, none of those homeowners used the one-measure strategy. All five homeowners were concerned about cost, comfort, and energy savings and included additional measures in their retrofits. The low-cost, one-measure strategy did not increase the uptake among homeowners, even in a well-educated, affluent community such as Davis.

Over the past 4 years, ARBI also worked with residential retrofit auditors and contractors in other parts of California on several retrofit programs. Through these programs, ARBI collected data about completed retrofits, including house characterization, pre- and post-retrofit energy use, and installed measures. ARBI has been using these data sets to develop energy models using the National Renewable Energy Laboratory's Building Energy Optimization software tool and appropriate data sets that are to be uploaded into the Building America Field Data Repository. ARBI has also synthesized marketing and outreach results from all these programs to develop lessons learned. Two key conclusions are: (1) a broad-based public awareness campaign is needed to increase understanding of the makeup and benefits of residential retrofits; and (2) a dramatic shift is needed in the economic playing field so that efficient homes are appraised and valued at higher levels than standard homes. The proposed Senate Bill 1106, Sensible Accounting to Value Energy Act of 2013, offers one way to accomplish this by adding the monthly cost of energy to that of principal, interest, taxes, and insurance when determining the cost of homeownership. Houses with lower energy costs would then be more highly valued, because the total cost of ownership is clearly lower for houses that are more efficient. 


\section{Introduction}

As the number of residential retrofits increases, working with industry partners to reduce costs through economies of scale and facilitate large numbers of retrofits is important. Local utilities, municipal and state governments, the federal government, manufacturers, and nonprofits all play important roles in advocating residential retrofit solutions to homeowners.

This project combined: (1) a program offering titled Retrofit Your Attic (RYA), which implemented an attic retrofit package — including attic insulation, air sealing, and duct sealingor replacement for homes in Davis, California; and (2) data collection for completed retrofits for homes throughout California, including house characterization, pre- and post-retrofit energy use, and installed measures. Twelve of these data sets were uploaded to the Building America Field Data Repository (BAFDR). Ten more will be uploaded by October 2014 now that BAFDR is back online.

The proposed work for this project was responsive to the gaps and barriers as defined by the various Building America standing technical committees, particularly:

- Identify and communicate lessons learned from the implementation of community-scale retrofit program strategies that would assist managers to achieve broad adoption.

- Populate BAFDR with pre- and post-energy assessment and utility data for completed home retrofits.

\subsection{Project Goals}

This project was directly relevant to the goals of the Building America program, which aims to reduce existing home energy use $50 \%$ by 2017 . The attic insulation/air sealing package promoted in this project is a high-impact, cost-effective approach that would contribute to such targets. While attic upgrades alone will not result in $50 \%$ building savings, enabling creative ideas to encourage uptake of home energy upgrades (HEUs) by reducing costs and simplifying the retrofit process is an important step to achieving Building America goals. A better understanding of actual measured savings is also critical to optimizing the building design process. The data collected in this project met Building America's goal to collect pre- and post-retrofit data about as many completed retrofits as possible and upload these data into BAFDR.

Several questions in this project focused on how to generate cost savings via community organizations and early adopters in promoting retrofits and what energy savings can be achieved through one specific measure. Technical considerations about acquisition and analysis of energy use data were considered as part of analyzing performance.

\subsection{Background}

Residential energy retrofit efforts have focused on whole-house energy upgrades to achieve $30 \%-50 \%$ energy reduction for a single home. While technically feasible, the high cost associated with deep retrofits makes them unattractive and unachievable for many homeowners and unfeasible for renters. More practically, retrofits can be offered as a low-cost package to an entire community, which makes consumer costs more manageable and still achieves communitywide energy reduction. 
One objective of this project was to facilitate retrofits of attic insulation, air sealing, and duct sealing. The target area was Davis, California, a hot-dry climate region that has approximately 25,000 households. Many homes in Davis were built in the 1960s and have little or no attic insulation, which heavily influences energy use for both heating and cooling. By analyzing the pre- and post-retrofit utility data for houses in which air and duct sealing and attic insulation were installed, energy savings could be quantified, calibrated against energy models, and analyzed using statistics. This would allow for improved characterization of the benefits of attic retrofits. This strategy also offered a relatively affordable retrofit that would yield a substantial reduction in energy use.

This program offered attic insulation retrofits to homeowners in Davis, California, to determine if more homeowners would participate in a single-measure retrofit than would spend thousands of dollars on a more complete energy upgrade. Through the two participating contractors in this program, the price for this attic retrofit package was approximately $\$ 4,000$ after incentives. The cost of the assessment was $\$ 99$, which the Cool Davis Initiative (CDI) covered.

The initial phase of this project included identifying target areas, developing outreach plans and materials, selecting installation contractors, and developing data collection and data processing methods. The next phase supported outreach activities to ensure participation.

Outreach efforts were undertaken through the volunteer network of the CDI along with the two participating contractors. CDI partners with more than 50 Davis-based community organizations and operates programs under the Cool Davis Foundation, a nonprofit 501(c) (3) (Fed ID 273056050). CDI used the available network (website, email listings, and booths at local events) to identify target neighborhoods and maximize participation. The group's 2015 goal is to engage $75 \%$ of Davis residents to reduce carbon emissions by 15\% below 1990 levels (Cool Davis undated). CDI uses localized neighborhood outreach to promote its activities, which includes neighborhood photovoltaic and solar thermal installations through the Energy Benefits Yolo Climate Compact (Group Energy 2013). This program offers group discounts on photovoltaic, solar thermal, electric vehicle charging stations, and energy-efficiency upgrades. CDI offers reduced cost assessments and installations by grouping outreach and retrofits based on location and working with specific contractors.

CDI identified a specific neighborhood that would benefit most from this single-retrofit measure program based on home vintage and roof style. The neighborhood consists of 406 homes, which were divided into two equal sections. The homeowners received email blasts detailing the program, the applicable Pacific Gas \& Electric (PG\&E) incentives, the names of both participating contractors, and invitations to a Cool Davis event held in Central Park where both contractors had booths. CDI provided volunteers to walk door to door in the two sections of the neighborhood with flyers and door hangers. Each section had its own message for the flyers and door hangers, potentially allowing the team to test the efficacy of the messages in the conversion rate of leads (homeowners who expressed interest in the program and provided contact information) to HEUs.

Another objective of this project was to initiate a community-scale data collection effort. Utility billing data are invaluable for calibrating and validating energy models. Utility data also increase the ability to disaggregate energy use. However, the data are valuable only if the house 
characteristics are known. The U.S. Department of Energy's Building America Research team, Alliance for Residential Building Innovation (ARBI), collected data about home retrofits throughout California through the Energy Upgrade California program and the Energy Benefits Yolo program. Together, these data sources provided substantial retrofit data. All useful data sets were uploaded to BAFDR for future use by all Building America teams. The results of this effort will help facilitate the Analysis Methods and Tools standing technical committees' critical path milestones of collecting and populating BAFDR. These data are needed to develop the Empirical Test Suites and Automated Calibration Methods 2015 milestones. 


\section{Research and Analysis}

The objective was to provide resources to encourage homeowners to complete air and duct sealing and to increase attic insulation levels to lower heating and cooling energy use. The ARBI team worked with CDI to develop an implementation strategy and group pricing for attic retrofits. ARBI recommended attic sealing and insulation specifications and prepared to calculate energy savings estimates via the National Renewable Energy Laboratory's Building Energy Optimization (BEopt ${ }^{\mathrm{TM}}$ ) software tool. The team also prepared to track homeowner participation and energy savings for completed retrofits and ARBI worked with the installing contractors to ensure best practices.

Research and analysis attempted to address the following questions:

1. How does the implementation of a targeted, community-based retrofit program that focused on a low-cost package in a single geographic area affect retrofit uptake?

2. What are the observed energy savings achieved by attic sealing, insulation upgrade, and other measures in older homes?

3. What are the gaps, challenges, and barriers in data acquisition from homeowners and how can they be overcome?

\subsection{Technical Approach}

To address the research questions, ARBI collected and analyzed data about marketing and outreach approaches. This information helped the team evaluate the effectiveness of various strategies of program design.

As part of the technical assessment process for RYA, ARBI:

- Determined the percentage of sales leads that completed home energy assessments (HEAs).

- Determined the percentage of HEAs that led to HEUs (i.e., conversion rate).

- Attempted to identify techniques for increasing conversion rates.

ARBI also developed criteria for homes for inclusion in the energy use data collection pilot, including:

- Houses built between 1970 and 1995

- Preferably production homes, because they are representative of large numbers of houses

- Preferably higher energy users

- Data acquisition requirements

- Access to $12+$ months pre-retrofit data

- Access to $12+$ months post-retrofit data matching the pre-retrofit data month for month 
- Minimum upgrade measures

$\bigcirc$ Air sealing

$\circ$ Duct sealing

- Attic insulation

- Pre- and post-retrofit test-in and test-out.

\subsection{Data Collection}

An important component of design and management of residential upgrade programs is measurement of actual energy savings. Greater understanding of energy savings results can enhance design aspects of retrofit programs such as performance guarantees and energy audits. As such, post-upgrade utility bill data must be collected if energy-efficiency programs are to succeed. Nevertheless, ARBI found that collecting billing data was quite challenging.

In a previous project, $\mathrm{ARBI}$ explored collecting utility bill data from a third-party platform, from homeowners, and from the utility. The platform used was MyEnergy, which has an arrangement with PG\&E, the utility provider. MyEnergy uses so-called crawler software that is designed to scan the electronic utility accounts of customers who sign up. The system was unreliable. It failed whenever the customer account page did not align perfectly with the crawler's template. This was precipitated by minor changes in PG\&E's Web pages and happened frequently. Persuading homeowners to register for the service also proved challenging. Some customers had security concerns; others were not computer savvy and did not know how to follow the sign-up directions. Even when ARBI offered to talk them through the process, they were reluctant or did not want to take the time. Attempts to persuade customers to provide utility bill data were only slightly more successful. Most customers do not keep 12 plus months of utility bills, others could not find them, and others promised to send copies but did not follow through.

During this project, ARBI's efforts to obtain billing data directly from PG\&E yielded better results; however, utilities are quite reluctant to release customers' billing data, even with signed releases. Utility billing systems were designed to create and send invoices, not to be a database from which inquiries can be easily made. Consequently, gathering and forwarding energy billing information for specific customers is time consuming for utility personnel. This created time delays. Eventually, however, ARBI successfully retrieved some data specifications. To expedite the process, Davis Energy Group (DEG) completed a thorough and arduous third-party security review with PG\&E's Third-Party Security Review Team. This process included encrypting many of DEG's files, reorganizing servers, enhancing firewalls, and other security measures. As of this writing, the speed and ease with which the team can gather custom energy use and billing data have not increased.

\subsection{Evaluation Methods}

ARBI uses empirical assessment methodologies to evaluate the effectiveness of implemented programs. Specifically, ARBI evaluates program implementation timeframes (time between leads, assessments, and upgrades), relationships between marketing approaches and sales outcomes, conversion rates, energy savings, consumer motivations, and more.

For the RYA project, the conversion rates of leads to HEAs, and HEAs to HEUs, were analyzed to compare the sales presentations of the two contractors working on the project. This analysis 
was used to determine if the way the information was presented to the homeowner affected the conversion rate.

Energy use and billing data were analyzed for completeness and the ability to do month-tomonth comparisons pre- and post-retrofit. Few data sets included all the components needed to properly analyze energy savings and attribute them to retrofit measures.

A methodology was established to disaggregate pre- and post-retrofit utility bill data for each household identifying and capturing the individual space conditioning and baseload behaviors. All the utility data were normalized to typical meteorological year (TMY3) ${ }^{1}$ weather data. In this investigation, the Stockton Metropolitan Airport TMY3 weather data were selected. This normalization procedure is necessary because weather profiles change yearly, so energy use needs to be standardized for comparison purposes.

The methodology outlined in ASHRAE's Inverse Modeling Toolkit (Kissock et al. 2004), which was developed in support of ASHRAE Guideline 14 (ASHRAE 2002), was followed for the disaggregation and normalization process. Pre- and post-retrofit energy use data were disaggregated into two main categories: baseload and weather-dependent. First, a regression model was identified to describe energy use as a function of influential variables, in this case weather. The regression capability of Excel and the LINEST function, which uses the least squares method, was used to develop a linear relationship between energy use, monthly heating degree days (HDDs) and monthly cooling degree days (CDDs). Separate regressions were developed for electricity and natural gas energy as well as for pre- and post-retrofit periods.

A variable-base degree-day model of the following type was used:

$$
\begin{gathered}
Y_{\text {elec }}=\beta_{1}+\beta_{2} * C D D+\beta_{3} * H D D \\
Y_{\text {gas }}=\beta_{1}+\beta_{2} * H D D
\end{gathered}
$$

where

$\mathrm{Y}$ is monthly energy consumption,

$\beta_{1}$ represents the constant term or baseload, and

$\beta_{2}$ and $\beta_{3}$ represent the variable coefficients that characterize dependence on weather.

CDDs and HDDs were used in the electricity regression to account for space cooling in the summer and fan energy during the heating season.

HDDs and CDDs in any given period are calculated as follows:

where

$$
\begin{aligned}
& C D D=\sum_{i=1}^{n}\left(T_{i}-a\right) \\
& H D D=\sum_{i=1}^{n}\left(b-T_{i}\right)
\end{aligned}
$$

\footnotetext{
${ }^{1}$ TMY3 weather data represent typical weather data from a particular weather station derived from 1991-2005 National Solar Radiation Data Base archives.
} 
$T_{i}$ is the daily average temperature and

$a$ and $b$ are the base temperatures for cooling and heating, respectively.

The base temperatures represent the average daily outdoor temperature above which space cooling is requested in the home and below which space heating is requested. The base temperatures were determined by solving for that which results in a regression model with the highest coefficient of determination or $\mathrm{R}^{2}$. This was accomplished by conducting the regression for successive base temperatures of $41^{\circ}-80^{\circ} \mathrm{F}$ to maximize $\mathrm{R}^{2}$. Pre- and post- retrofit periods were evaluated separately to account for changes in interior conditions and comfort, which may affect the base temperature.

For this analysis, the space heating and water heating fuel was assumed to be natural gas because the saturations were $94 \%$ and $95 \%$, respectively, for single-family homes with natural gas accounts in California (CEC 2010). The natural gas baseload was assumed to be represented primarily by water heating. Cooking and clothes drying may also contribute to the gas baseload, but this level of detail was not known about individual houses. The calculated natural gas baseload from the regression was revised to reflect the seasonality and weather dependence of this end use. DEG monitored the water heating of several existing homes in the California Central Valley. The results revealed that peak winter use is roughly twice that of peak summer use. Annual load profiles from this research were applied to the regression results.

Lastly, CDDs and HDDs calculated from TMY3 weather data were applied to the identified relationship to estimate normalized heating and cooling energy use and subsequently energy savings between the pre-retrofit and post-retrofit periods. Baseload energy use was assumed to be the same for actual and TMY3 weather conditions.

Results for each house were reviewed. In general, results with $\mathrm{R}^{2}$ values of 0.75 or higher were deemed statistically relevant. However, given the potential variability of occupancy in residential homes, which cannot mathematically be accounted for in this regression, numerous data sets reported statistics that were lower than this threshold. If review of monthly load profiles of the disaggregated data appeared reasonable, these results were retained. Other data sets reported good statistical alignment; however, further review identified results such as unreasonably low baseload variation over the year or negative heating or cooling energy estimates. These data sets were manually tweaked to better align estimated monthly space conditioning energy use with the monthly weather. In some cases, this involved manually varying the base temperatures. In others, outliers were removed where low energy use indicated unoccupied periods. In three cases, the team determined that measured electricity use had no relevant relationship with weather. Neither the disaggregated nor the normalized energy use for these homes is presented in this analysis.

In most data sets a relationship between electricity use and HDDs was clear; however, heating electricity use was consistently overestimated in this process. This is likely a result of the increase in nonspace heating electricity consumption, primarily lighting, during the winter months. However, the makeup of electric baseload (i.e., percent lighting, appliances, and plug loads) is highly variable and difficult to estimate for any home. Thus, electric space heating was not disaggregated in the final results and was instead included in the baseload. This was determined to be a conservative approach that underestimates salient heating energy savings. 
In many cases, the electricity baseload differed between the pre- and post-retrofit cases. This may reflect general changes in occupancy or changes to the lighting, appliances, or plug loads in the home. The HEUs evaluated did not incorporate any measures that targeted these end uses (lighting upgrades, ENERGY STAR ${ }^{\circledR}$ refrigerators, etc.). Therefore, for savings calculations the TMY3 electricity baseload was defined as the average between the pre- and post-retrofit period baseloads. The same applied to the natural gas baseload. However, some of the HEUs did include water heater upgrades, the savings for which would be reflected in the natural gas baseload. For those houses, the savings associated with the change in baseload were included in the results. For the remaining house, an average of the baseloads was applied to both the pre- and post-retrofit cases. Any changes in occupancy or system operation (i.e., thermostat set point) within the targeted end uses (space cooling, space heating, and domestic hot water) were inherently included in the evaluated savings. 


\section{$3 \quad$ Results}

\subsection{Retrofit Your Attic}

The RYA program team, including ARBI and CDI, interviewed potential participating contractors and decided on two: Green Home Solutions, a sales-oriented general contractor, and Brower Mechanical, a heating, ventilating, and air-conditioning (HVAC) company. CDI determined the best neighborhood in Davis for the program. This neighborhood of similar housing stock contained 406 houses that could be easily divided into two sections. The team worked with the two contractors to determine outreach strategies and marketing messages to be used in the two sections of the neighborhood, along with the data that would be collected for each retrofit.

The expected results for this project were:

- Enhanced uptake, because homeowners would take advantage of a prepriced retrofit with fewer measures that cost less than $\$ 4,000$ after incentives as opposed to a full-blown retrofit that costs thousands more

- Continued challenges collecting utility data even with signed homeowner release forms, because utilities are reluctant to provide data that may conflict with privacy and other considerations

- Greater interest and participation in Davis compared to other cities, because more energyconcerned citizens and environmentalists live in this college town than in many others.

Outreach efforts for this program included contractor booths at the widely attended Cool Davis event held in Davis' Central Park, on October 12, 2013, email blasts using CDI's city email database, and an article in the Davis Enterprise. CDI volunteers walked each section of the neighborhood during two weekends. The first weekend was before the Cool Davis event in Central Park, so the volunteers talked about the program and invited homeowners to attend and meet the contractors at the Cool Davis event. The second weekend of door-to-door outreach took place after the Cool Davis event as a follow-up to help the message stay "top of mind" for homeowners in the targeted neighborhood. During both weekends, contractor personnel were available to the volunteers to schedule assessments and answer technical questions.
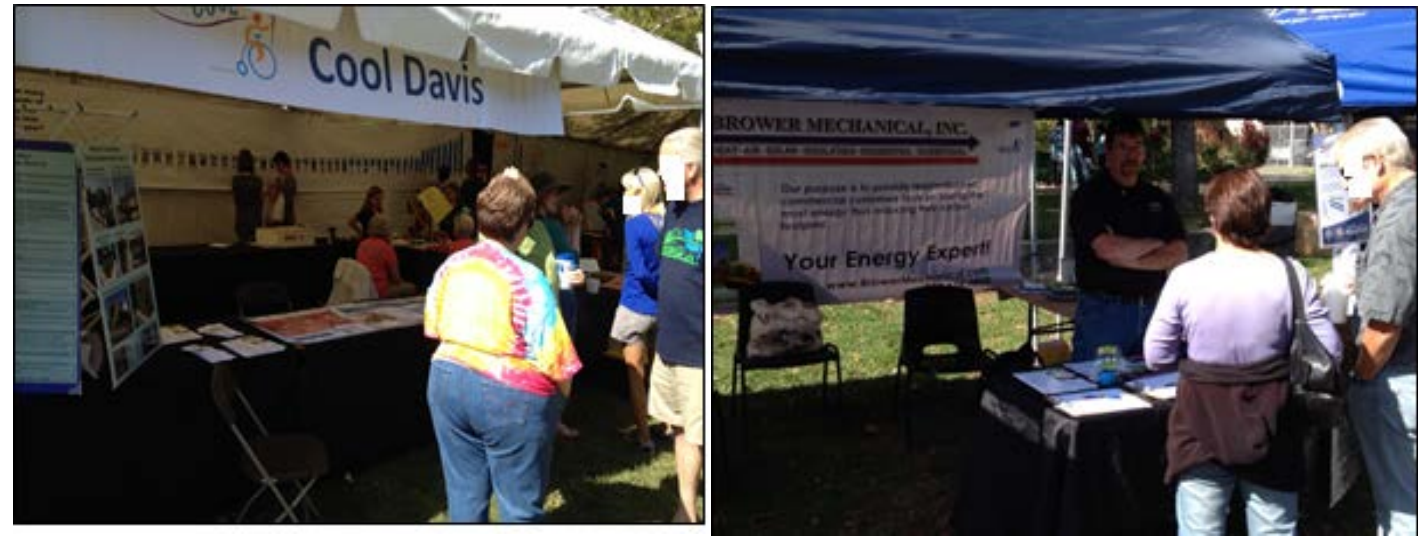

Figure 1. Booths at Cool Davis Event, October 12, 2013 
One lesson learned was that the contractor more familiar with working with volunteer groups had more realistic expectations of what the volunteers might accomplish. Initially, many more than a dozen volunteers were scheduled for the weekend door-to-door canvassing. Several backed out, others did not show up, and the eight that did show up had no technical backgrounds or personal retrofit experience on their own homes to give them the confidence to have viable conversations about the program with the homeowners.

Another lesson learned was that when working with a volunteer group, reports about the data they were collecting were typically submitted significantly late or not at all. Unfortunately, as volunteers they have their own timetables, which rarely coincide with program needs.

Table 1 shows the outreach results achieved by eight CDI volunteers and contractor personnel during the first weekend of door-to-door outreach. A total of 376 homes were visited, in some cases multiple times.

Table 1. Volunteer Door-to-Door Outreach Results

\begin{tabular}{|c|c|c|c}
\hline Contact Type & Total & $\begin{array}{c}\text { \% of Map } \\
\text { House Count }\end{array}$ & $\begin{array}{c}\text { \% of Home } \\
\text { Visits }\end{array}$ \\
\hline Unreachable-No Solicitors & 30 & $7 \%$ & $8 \%$ \\
\hline Door Hangers (no one at home) & 221 & $54 \%$ & $59 \%$ \\
Handout Flyer & 103 & $25 \%$ & $27 \%$ \\
Conversations & 155 & $38 \%$ & $41 \%$ \\
Total Multiple Contacts & 458 & $113 \%$ & $122 \%$ \\
Total Homes Visited & 376 & $93 \%$ & $100 \%$ \\
\hline
\end{tabular}

Unfortunately, the overall results, as shown in Table 2 below, were lower than anticipated for this cost-effective, simple program in a community that touts sustainability as a core concern. Of the 41 leads generated, 37\% elected to get a Home Energy Assessment. Of those receiving an HEA, 33\% chose to move ahead with a retrofit. The percentage of leads that completed an HEU was $12 \%(0.33 \times 0.37)$, similar to that seen in other retrofit programs.

Table 2. Overall Results

\begin{tabular}{c|c|c|c}
\hline & Leads & HEAs & HEUs \\
\hline Green Home Solutions & 29 & 10 & 3 \\
Brower Mechanical & 12 & 5 & 2 \\
Total & 41 & 15 & 5 \\
\hline
\end{tabular}

The main reason given for not converting from an HEA to HEU was cost. Other observations were the same lack of awareness or sense of urgency that ARBI saw in other retrofit programs throughout the state. The low cost of less than $\$ 4,000$ (after incentives) still was not low enough for Davis homeowners. Even in Davis, most homeowners expect the utility incentives to cover nearly all the cost of completing an HEU.

Cost effectiveness was evaluated using BEopt modeling to predict utility cost savings of one of the homes in our data sample. The upgrade of a 1,897- $\mathrm{ft}^{2}$ house built in 1976 with attic insulation and envelope and duct sealing at a cost of approximately $\$ 4,000$ (after incentives) resulted in 
projected utility bill savings of about $\$ 340$ annually. The simple payback for the homeowner is about 12.5 years. This timeframe is not attractive to homeowners who already believe the cost of the upgrade is too high.

\subsection{Data Collection}

The data collection for California homes participating in retrofit programs such as RYA and Energy Upgrade California continues to be a laborious process. ARBI, through DEG, completed PG\&E's Third-Party Security Review requirements to receive security clearance. This allowed the team to submit its first confidential homeowner utility data request in June 2014. This 6month process was time intensive, but should expedite the utility data collection process.

Working with a local contractor, ARBI was able to collect data about 31 homes in the hot-dry climate of Stockton, California. For houses where pre- and post-retrofit utility data were available, ARBI followed this protocol to upload the appropriate data into BAFDR:

- Uploaded data only about houses that had utility data, preferably 12 months pre- and post-retrofit.

- Created two BEopt models of each house, one in pre-retrofit condition and one with retrofit measures installed.

- Exported the final product in HPXML format and uploaded it to BAFDR along with all available utility data.

ARBI has uploaded data sets for 21 houses.

Collected data that were analyzed for pre- and post-retrofit energy use indicate that some homes yield greater-than-predicted energy savings; others underperform relative to predicted savings. Heterogeneity in consumer motivations and post-retrofit behavior is an important aspect of the market for program managers to recognize, because energy savings do not necessarily dominate all homeowner decisions.

Homeowners may instigate considerable take-back. Nonetheless, homeowners reported being satisfied with their retrofits, because improved comfort appears to trump energy savings. Also, the potential for energy savings is higher in retrofit houses if energy costs rise in the future, because these houses can cut back on energy and still maintain minimal comfort. Inefficient houses that are not retrofitted are already uncomfortable and are less able to cut back further.

Table 3 includes a summary of the HEU measures and total costs for 31 homes analyzed. Data sets that have house characterization information loaded into BAFDR are marked with a check mark $(\checkmark)$. A minimum of 12 months of pre- and post-retrofit utility data were required to include the house in the energy savings analysis. Only 24 single-family residences met this threshold. This reflects the challenge of acquiring detailed utility bill data. Table 4 presents electricity and natural gas savings by house. Of the 24 data points, three houses (\#44, \#53, and \#54) had no defensible relationship between monthly electricity use and degree-days; therefore, electricity data for these sites are not presented in Table 4 and are not included in this analysis.

The measures implemented in the HEUs reported generally resulted in a decrease in total home energy consumption for both electricity and natural gas. On average, total electricity use 
decreased by $570 \mathrm{kWh}$ or $6.9 \%$ and total natural gas use by 53 therms or $9.7 \%$. However, four houses experienced increases in electricity use and nine houses experienced increases in natural gas use after the retrofit. Some of this can be attributed to take-back when occupants demanded increased comfort (discussed further below). This is most apparent where households installed central HVAC systems for the first time, replacing space-heating systems. This was the case for households \#37 and \#54. Savings attributable to individual measures is difficult to identify given the sample size, the multiple combinations of measures, various relative improvements from preto post- retrofit cases (i.e. reduction in envelope leakage), and uncertainty about occupancy in the home (i.e., take-back). 
Table 3. HEU Measures Installed in 31 Hot-Dry Climate Residences

\begin{tabular}{|c|c|c|c|c|c|c|c|c|c|}
\hline $\begin{array}{c}\text { Reference } \\
\text { Household } \\
\text { ID } \\
\text { BAFDR }\end{array}$ & $\begin{array}{c}\text { Attic } \\
\text { Insulation }\end{array}$ & $\begin{array}{c}\text { Building } \\
\text { Envelope } \\
\text { Leakage } \\
\text { (after } \\
\text { sealing) }\end{array}$ & $\begin{array}{c}\text { HVAC } \\
\text { Duct } \\
\text { Leakage } \\
\text { (after } \\
\text { sealing) }\end{array}$ & $\begin{array}{c}\text { HVAC Duct } \\
\text { Insulation } \\
\text { (R-Value) }\end{array}$ & $\begin{array}{c}\text { Windows } \\
\text { (U-Factor/ } \\
\text { SHGC }^{\mathbf{a}} \text { ) }\end{array}$ & $\begin{array}{c}\text { Domestic } \\
\text { Water } \\
\text { Heater }\end{array}$ & $\begin{array}{c}\text { Wall } \\
\text { Insulation }\end{array}$ & $\begin{array}{c}\text { HVAC } \\
\text { Upgrades or } \\
\text { Changes }\end{array}$ & $\begin{array}{l}\text { Total } \\
\text { Cost }\end{array}$ \\
\hline 4 & $\begin{array}{c}\checkmark \\
\text { R-38 }\end{array}$ & & & & & & & & $\$ 535$ \\
\hline $10 *$ & $\begin{array}{c}\checkmark \\
\text { R-38 }\end{array}$ & $\begin{array}{c}\checkmark \\
6.7 \mathrm{SLA}^{\mathrm{b}}\end{array}$ & $\begin{array}{c}\checkmark \\
9 \%\end{array}$ & $\begin{array}{c}\checkmark \\
6.0\end{array}$ & & $\begin{array}{c}\checkmark \\
\mathrm{GF}^{\mathrm{c}}, 50 \mathrm{gal}, \\
0.62 \mathrm{EF}^{\mathrm{d}}\end{array}$ & & & $\$ 9,785$ \\
\hline 11 & $\begin{array}{c}\checkmark \\
\text { R-38 }\end{array}$ & $\begin{array}{c}\checkmark \\
\text { 5.9 SLA }\end{array}$ & $\begin{array}{c}\checkmark \\
9 \%\end{array}$ & $\begin{array}{c}\checkmark \\
6.0\end{array}$ & & $\begin{array}{c}\checkmark \\
\mathrm{GF}, 50 \text { gal, } \\
0.62 \mathrm{EF}\end{array}$ & & & $\$ 10,150$ \\
\hline 14 & $\begin{array}{c}\checkmark \\
\mathrm{R}-38\end{array}$ & $\begin{array}{c}\checkmark \\
\text { 4.4 SLA }\end{array}$ & $\begin{array}{c}\checkmark \\
13 \%\end{array}$ & & $\begin{array}{c}\checkmark \\
0.3 / 0.3\end{array}$ & $\begin{array}{c}\checkmark \\
\mathrm{GF}, 50 \mathrm{gal}, \\
0.62 \mathrm{EF}\end{array}$ & & & $\$ 15,875$ \\
\hline $15^{*}$ & $\begin{array}{c}\checkmark \\
\mathrm{R}-38\end{array}$ & & $\begin{array}{c}\checkmark \\
6 \%\end{array}$ & $\begin{array}{c}\checkmark \\
6.0\end{array}$ & $\begin{array}{c}\checkmark \\
0.3 / 0.3\end{array}$ & $\begin{array}{c}\checkmark \\
\mathrm{GF}, 50 \mathrm{gal}, \\
0.62 \mathrm{EF}\end{array}$ & & & $\$ 17,227$ \\
\hline $16^{*}$ & $\begin{array}{c}\checkmark \\
\text { R-38 }\end{array}$ & & $\begin{array}{c}\checkmark \\
12 \%\end{array}$ & & $\begin{array}{c}\checkmark \\
0.3 / 0.3\end{array}$ & $\begin{array}{c}\checkmark \\
\mathrm{GF}, 50 \mathrm{gal}, \\
0.62 \mathrm{EF}\end{array}$ & & $\begin{array}{c}\checkmark \\
\text { AFUE }^{\mathrm{e}} 80 \% \\
\text { SEER }^{\mathrm{f}} 13.0 \\
\text { EER }^{\mathrm{g}} 12.0\end{array}$ & $\$ 21,275$ \\
\hline 17 & $\begin{array}{c}\checkmark \\
\mathrm{R}-38\end{array}$ & & $\begin{array}{c}\checkmark \\
12 \%\end{array}$ & & & $\begin{array}{c}\checkmark \\
\mathrm{GF}, 50 \mathrm{gal}, \\
0.62 \mathrm{EF}\end{array}$ & $\begin{array}{c}\checkmark \\
\mathrm{R}-13\end{array}$ & & $\$ 11,270$ \\
\hline $18 *$ & $\begin{array}{c}\checkmark \\
\mathrm{R}-38\end{array}$ & $\begin{array}{c}\checkmark \\
\text { 4.0 SLA }\end{array}$ & $\begin{array}{c}\checkmark \\
6 \%\end{array}$ & $\begin{array}{c}\checkmark \\
6.0\end{array}$ & $\begin{array}{c}\checkmark \\
0.4 / 0.4\end{array}$ & $\begin{array}{c}\checkmark \\
\mathrm{GF}, 50 \mathrm{gal}, \\
0.62 \mathrm{EF}\end{array}$ & & $\begin{array}{c}\checkmark \\
\text { AFUE 80\% } \\
\text { SEER 13.0 } \\
\text { EER } 12.0\end{array}$ & $\$ 29,035$ \\
\hline
\end{tabular}




\begin{tabular}{|c|c|c|c|c|c|c|c|c|c|}
\hline $\begin{array}{c}\text { Reference } \\
\text { Household } \\
\text { ID } \\
\text { BAFDR }\end{array}$ & $\begin{array}{c}\text { Attic } \\
\text { Insulation }\end{array}$ & $\begin{array}{c}\text { Building } \\
\text { Envelope } \\
\text { Leakage } \\
\text { (after } \\
\text { sealing) }\end{array}$ & $\begin{array}{c}\text { HVAC } \\
\text { Duct } \\
\text { Leakage } \\
\text { (after } \\
\text { sealing) }\end{array}$ & $\begin{array}{c}\text { HVAC Duct } \\
\text { Insulation } \\
\text { (R-Value) }\end{array}$ & $\begin{array}{c}\text { Windows } \\
\text { (U-Factor/ } \\
\text { SHGC }^{\mathbf{a}} \text { ) }\end{array}$ & $\begin{array}{l}\text { Domestic } \\
\text { Water } \\
\text { Heater }\end{array}$ & $\begin{array}{c}\text { Wall } \\
\text { Insulation }\end{array}$ & $\begin{array}{c}\text { HVAC } \\
\text { Upgrades or } \\
\text { Changes }\end{array}$ & $\begin{array}{l}\text { Total } \\
\text { Cost }\end{array}$ \\
\hline 19 & $\begin{array}{c}\checkmark \\
\text { R-49 }\end{array}$ & $\begin{array}{c}\checkmark \\
3.2 \mathrm{SLA}\end{array}$ & $\begin{array}{c}\checkmark \\
8 \%\end{array}$ & & $\begin{array}{c}\checkmark \\
0.3 / 0.3\end{array}$ & $\begin{array}{c}\checkmark \\
\mathrm{GF}, 50 \mathrm{gal}, \\
0.62 \mathrm{EF}\end{array}$ & & $\begin{array}{c}\checkmark \\
\text { AFUE 80\% } \\
\text { SEER } 13.0 \\
\text { EER } 12.0\end{array}$ & $\$ 21,810$ \\
\hline 27 & & & & & $\begin{array}{c}\checkmark \\
0.3 / 0.3\end{array}$ & & & & $\$ 11,795$ \\
\hline 31 & $\begin{array}{c}\checkmark \\
\mathrm{R}-38\end{array}$ & $\begin{array}{c}\checkmark \\
3.6 \mathrm{SLA}\end{array}$ & $\begin{array}{c}\checkmark \\
4 \%\end{array}$ & $\begin{array}{l}\checkmark \\
6.0\end{array}$ & $\begin{array}{c}\checkmark \\
0.3 / 0.3\end{array}$ & & & $\begin{array}{c}\checkmark \\
\text { AFUE 80\% } \\
\text { SEER 13.0 } \\
\text { EER } 12.0\end{array}$ & $\$ 31,125$ \\
\hline 33 & $\begin{array}{c}\checkmark \\
\mathrm{R}-38\end{array}$ & & & & $\begin{array}{c}\checkmark \\
0.3 / 0.3\end{array}$ & & & $\begin{array}{c}\checkmark \\
\text { AFUE 80\% } \\
\text { SEER 14.0 } \\
\text { EER } 12.0\end{array}$ & $\$ 27,145$ \\
\hline $37 *$ & $\begin{array}{c}\checkmark \\
\mathrm{R}-38\end{array}$ & & $\begin{array}{c}\checkmark \\
3 \%\end{array}$ & $\begin{array}{l}\checkmark \\
6.0\end{array}$ & & & $\begin{array}{c}\checkmark \\
\mathrm{R}-13\end{array}$ & $\begin{array}{c}\checkmark \\
\text { AFUE 80\% } \\
\text { SEER } 13.0 \\
\text { EER } 12.0\end{array}$ & $\$ 14,750$ \\
\hline $40 *$ & $\begin{array}{c}\checkmark \\
\mathrm{R}-38\end{array}$ & & $\begin{array}{c}\checkmark \\
6 \%\end{array}$ & $\begin{array}{l}\checkmark \\
6.0\end{array}$ & & $\begin{array}{c}\checkmark \\
\mathrm{GF}, 50 \mathrm{gal}, \\
0.62 \mathrm{EF}\end{array}$ & & $\begin{array}{c}\checkmark \\
\text { AFUE 80\% } \\
\text { SEER 13.0 } \\
\text { EER 12.0 }\end{array}$ & $\$ 14,255$ \\
\hline $41 *$ & $\begin{array}{c}\checkmark \\
\mathrm{R}-38\end{array}$ & & $\begin{array}{c}\checkmark \\
10 \%\end{array}$ & $\begin{array}{l}\checkmark \\
6.0\end{array}$ & & $\begin{array}{c}\checkmark \\
\mathrm{GF}, 50 \mathrm{gal}, \\
0.62 \mathrm{EF}\end{array}$ & & $\begin{array}{c}\checkmark \\
\text { AFUE 80\% } \\
\text { SEER 13.0 } \\
\text { EER } 12.0\end{array}$ & $\$ 31,625$ \\
\hline 42 & $\begin{array}{c}\checkmark \\
\text { R-38 }\end{array}$ & $\begin{array}{c}\checkmark \\
\text { 5.6 SLA }\end{array}$ & & & $\begin{array}{c}\checkmark \\
0.3 / 0.3\end{array}$ & & & & $\$ 17,340$ \\
\hline
\end{tabular}




\begin{tabular}{|c|c|c|c|c|c|c|c|c|c|}
\hline $\begin{array}{c}\text { Reference } \\
\text { Household } \\
\text { ID } \\
\text { BAFDR }\end{array}$ & $\begin{array}{c}\text { Attic } \\
\text { Insulation }\end{array}$ & $\begin{array}{c}\text { Building } \\
\text { Envelope } \\
\text { Leakage } \\
\text { (after } \\
\text { sealing) }\end{array}$ & $\begin{array}{c}\text { HVAC } \\
\text { Duct } \\
\text { Leakage } \\
\text { (after } \\
\text { sealing) }\end{array}$ & $\begin{array}{c}\text { HVAC Duct } \\
\text { Insulation } \\
\text { (R-Value) }\end{array}$ & $\begin{array}{l}\text { Windows } \\
\text { (U-Factor/ } \\
\text { SHGC }^{\mathbf{a}} \text { ) }\end{array}$ & $\begin{array}{c}\text { Domestic } \\
\text { Water } \\
\text { Heater }\end{array}$ & $\begin{array}{c}\text { Wall } \\
\text { Insulation }\end{array}$ & $\begin{array}{c}\text { HVAC } \\
\text { Upgrades or } \\
\text { Changes }\end{array}$ & $\begin{array}{l}\text { Total } \\
\text { Cost }\end{array}$ \\
\hline $44^{*}$ & $\begin{array}{c}\checkmark \\
\mathrm{R}-38\end{array}$ & & $\begin{array}{c}\checkmark \\
6 \%\end{array}$ & & & $\begin{array}{c}\checkmark \\
\mathrm{GF}, 50 \mathrm{gal}, \\
0.90 \mathrm{EF}\end{array}$ & & $\begin{array}{c}\checkmark \\
\text { AFUE 95\% } \\
\text { SEER } 16.0 \\
\text { EER } 14.0\end{array}$ & $\$ 27,730$ \\
\hline 49 & $\begin{array}{c}\checkmark \\
\text { R-38 }\end{array}$ & $\begin{array}{c}\checkmark \\
4.5 \text { SLA }\end{array}$ & $\begin{array}{c}\checkmark \\
5 \%\end{array}$ & & & & & & $\$ 4,060$ \\
\hline $52 *$ & $\begin{array}{c}\checkmark \\
\mathrm{R}-38\end{array}$ & $\begin{array}{c}\checkmark \\
3.1 \text { SLA }\end{array}$ & $\begin{array}{c}\checkmark \\
12 \%\end{array}$ & & $\begin{array}{c}\checkmark \\
0.3 / 0.3\end{array}$ & & & & $\$ 14,700$ \\
\hline $53 *$ & $\begin{array}{c}\checkmark \\
\text { R-49 }\end{array}$ & $\begin{array}{c}\checkmark \\
2.9 \text { SLA }\end{array}$ & $\begin{array}{c}\checkmark \\
5 \%\end{array}$ & $\begin{array}{c}\checkmark \\
6.0\end{array}$ & & & & & $\$ 8,485$ \\
\hline $54 *$ & & $\begin{array}{c}\checkmark \\
\text { 4.1 SLA }\end{array}$ & $\begin{array}{c}\checkmark \\
4 \%\end{array}$ & $\begin{array}{l}\checkmark \\
6.0\end{array}$ & & $\begin{array}{c}\checkmark \\
\text { GF, tankless, } \\
0.88 \text { EF }\end{array}$ & & $\begin{array}{c}\checkmark \\
\text { AFUE 80\% } \\
\text { SEER 13.0 } \\
\text { EER } 12.0\end{array}$ & $\$ 20,310$ \\
\hline $57 *$ & & & & & $\begin{array}{c}\checkmark \\
0.3 / 0.3\end{array}$ & & & & $\$ 7,260$ \\
\hline 65 & $\begin{array}{c}\checkmark \\
R-38\end{array}$ & & $\begin{array}{c}\checkmark \\
14 \%\end{array}$ & & & & $\begin{array}{c}\checkmark \\
R-13\end{array}$ & & $\$ 8,960$ \\
\hline 73 & $\begin{array}{c}\checkmark \\
\mathrm{R}-49\end{array}$ & $\begin{array}{c}\checkmark \\
5.2 \mathrm{SLA}\end{array}$ & & & $\begin{array}{c}\checkmark \\
0.3 / 0.3\end{array}$ & $\begin{array}{c}\checkmark \\
\mathrm{GF}, 50 \mathrm{gal}, \\
0.62 \mathrm{EF}\end{array}$ & & $\begin{array}{c}\checkmark \\
\text { AFUE 80\% } \\
\text { SEER 13.0 } \\
\text { EER } 12.0\end{array}$ & $\$ 27,380$ \\
\hline 78 & $\begin{array}{c}\checkmark \\
\mathrm{R}-39\end{array}$ & $\begin{array}{c}\checkmark \\
4.4 \mathrm{SLA}\end{array}$ & $\begin{array}{c}\checkmark \\
6 \%\end{array}$ & $\begin{array}{l}\checkmark \\
6.0\end{array}$ & & & & $\begin{array}{c}\checkmark \\
\text { AFUE 80\% } \\
\text { SEER 13.0 } \\
\text { EER } 12.0\end{array}$ & $\$ 8,580$ \\
\hline
\end{tabular}




\begin{tabular}{|c|c|c|c|c|c|c|c|c|c|}
\hline $\begin{array}{c}\text { Reference } \\
\text { Household } \\
\text { ID } \\
\text { BAFDR }\end{array}$ & $\begin{array}{c}\text { Attic } \\
\text { Insulation }\end{array}$ & $\begin{array}{c}\text { Building } \\
\text { Envelope } \\
\text { Leakage } \\
\text { (after } \\
\text { sealing) }\end{array}$ & $\begin{array}{c}\text { HVAC } \\
\text { Duct } \\
\text { Leakage } \\
\text { (after } \\
\text { sealing) }\end{array}$ & $\begin{array}{c}\text { HVAC Duct } \\
\text { Insulation } \\
\text { (R-Value) }\end{array}$ & $\begin{array}{l}\text { Windows } \\
\text { (U-Factor/ } \\
\text { SHGC }^{\mathbf{a}} \text { ) }\end{array}$ & $\begin{array}{c}\text { Domestic } \\
\text { Water } \\
\text { Heater }\end{array}$ & $\begin{array}{c}\text { Wall } \\
\text { Insulation }\end{array}$ & $\begin{array}{c}\text { HVAC } \\
\text { Upgrades or } \\
\text { Changes }\end{array}$ & $\begin{array}{l}\text { Total } \\
\text { Cost }\end{array}$ \\
\hline 85 & & & & & & $\begin{array}{c}\checkmark \\
\mathrm{GF}, 50 \mathrm{gal}, \\
0.62 \mathrm{EF}\end{array}$ & & & $\$ 1,090$ \\
\hline 91 & $\begin{array}{c}\checkmark \\
\mathrm{R}-38\end{array}$ & & & & & & & $\begin{array}{c}\checkmark \\
\text { AFUE 80\% } \\
\text { SEER } 16.0 \\
\text { EER } 14.0\end{array}$ & $\$ 16,765$ \\
\hline 92 & $\begin{array}{c}\checkmark \\
\mathrm{R}-38\end{array}$ & $\begin{array}{c}\checkmark \\
3.6 \text { SLA }\end{array}$ & $\begin{array}{c}\checkmark \\
6 \%\end{array}$ & $\begin{array}{l}\checkmark \\
6.0\end{array}$ & $\begin{array}{c}\checkmark \\
0.3 / 0.3\end{array}$ & & & $\begin{array}{c}\checkmark \\
\text { AFUE } 80 \% \\
\text { SEER } 16.0 \\
\text { EER } 13.0\end{array}$ & $\$ 15,305$ \\
\hline 116 & $\begin{array}{c}\checkmark \\
\mathrm{R}-38\end{array}$ & $\begin{array}{c}\checkmark \\
3.2 \text { SLA }\end{array}$ & $\begin{array}{c}\checkmark \\
5 \%\end{array}$ & $\begin{array}{c}\checkmark \\
6.0\end{array}$ & & & & $\begin{array}{c}\checkmark \\
\text { AFUE } 80 \% \\
\text { SEER } 13.0 \\
\text { EER } 11.0\end{array}$ & $\$ 18,090$ \\
\hline SMRS** & $\begin{array}{c}\checkmark \\
\mathrm{R}-38\end{array}$ & $\begin{array}{c}\checkmark \\
1.7 \mathrm{SLA}\end{array}$ & $\begin{array}{c}\checkmark \\
14 \%\end{array}$ & & & $\begin{array}{c}\checkmark \\
\mathrm{GF}, 50 \mathrm{gal}, \\
0.62 \mathrm{EF}\end{array}$ & & & $\$ 11,174$ \\
\hline STKG** & $\begin{array}{c}\checkmark \\
\text { R-49 }\end{array}$ & & $\begin{array}{c}\checkmark \\
15 \%\end{array}$ & $\begin{array}{c}\checkmark \\
8.0\end{array}$ & $\begin{array}{c}\checkmark \\
0.3 / 0.3\end{array}$ & $\begin{array}{c}\checkmark \\
\text { GF, tankless, } \\
0.96 \mathrm{EF}\end{array}$ & & $\begin{array}{c}\checkmark \\
\text { AFUE 95\% } \\
\text { SEER 16.0 } \\
\text { EER 12.0 }\end{array}$ & $\$ 31,272$ \\
\hline
\end{tabular}

* BAFDR

* Code names assigned to houses

${ }^{\mathrm{a}}$ solar heat gain coefficient; ${ }^{\mathrm{b}}$ specific leakage area $;{ }^{\mathrm{c}}$ gas-fired; ${ }^{\mathrm{d}}$ energy factor; ${ }^{\mathrm{e}}$ annual fuel utilization efficiency; ${ }^{\mathrm{f}}$ seasonal energy-efficiency ratio; ${ }^{\mathrm{g}}$ energyefficiency ratio 
Table 4. Total Electricity and Natural Gas Savings From the HEUs

\begin{tabular}{|c|c|c|c|c|c|c|c|c|}
\hline \multirow{2}{*}{$\begin{array}{l}\text { Reference } \\
\text { Household } \\
\text { Number }\end{array}$} & \multicolumn{4}{|c|}{$\begin{array}{c}\text { Total Electricity Usage- } \\
\text { Normalized to TMY3 } \\
\text { (kWh) }\end{array}$} & \multicolumn{4}{|c|}{$\begin{array}{c}\text { Total Natural Gas Usage- } \\
\text { Normalized to TMY3 } \\
\text { (therm) }\end{array}$} \\
\hline & Pre & Post & Savings & $\begin{array}{c}\% \\
\text { Savings }\end{array}$ & Pre & Post & Savings & $\begin{array}{c}\% \\
\text { Savings }\end{array}$ \\
\hline 18 & 6,665 & 6,292 & 373 & $5.6 \%$ & 293 & 337 & -44 & $-15.0 \%$ \\
\hline 19 & 8,959 & 7,726 & 1,233 & $13.8 \%$ & 348 & 319 & 29 & $8.3 \%$ \\
\hline 27 & 9,922 & 9,551 & 371 & $3.7 \%$ & 696 & 606 & 90 & $12.9 \%$ \\
\hline 31 & 13,289 & 10,269 & 3,020 & $22.7 \%$ & 562.5 & 627.5 & -65 & $-11.6 \%$ \\
\hline 33 & 13,339 & 12,529 & 810 & $6.1 \%$ & 598.5 & 601.5 & -3 & $-0.5 \%$ \\
\hline 37 & 4,177 & 4,287 & -110 & $-2.6 \%$ & 150 & 315 & -165 & $-110.0 \%$ \\
\hline 40 & 9,009 & 8,267 & 742 & $8.2 \%$ & 800 & 466 & 334 & $41.8 \%$ \\
\hline 41 & 11,355 & 11,418 & -63 & $-0.6 \%$ & 925 & 603 & 322 & $34.8 \%$ \\
\hline 42 & 9,059 & 8,430 & 629 & $6.9 \%$ & 476 & 376 & 100 & $21.0 \%$ \\
\hline 44 & - & - & - & - & 516 & 394 & 122 & $23.6 \%$ \\
\hline 49 & 6,753 & 6,647 & 106 & $1.6 \%$ & 593.5 & 631.5 & -38 & $-6.4 \%$ \\
\hline 52 & 4,983 & 4,812 & 171 & $3.4 \%$ & 421 & 402 & 19 & $4.5 \%$ \\
\hline 53 & - & - & - & - & 761 & 650 & 111 & $14.6 \%$ \\
\hline 54 & - & - & - & - & 536 & 640 & -104 & $-19.4 \%$ \\
\hline 57 & 7,940 & 8,009 & -69 & $-0.9 \%$ & 568.5 & 500.5 & 68 & $12.0 \%$ \\
\hline 65 & 4,377 & 4,147 & 230 & $5.3 \%$ & 701.5 & 591.5 & 110 & $15.7 \%$ \\
\hline 73 & 6,906 & 6,303 & 603 & $8.7 \%$ & 688 & 612 & 76 & $11.0 \%$ \\
\hline 78 & 8,416 & 8,114 & 302 & $3.6 \%$ & 447.5 & 511.5 & -64 & $-14.3 \%$ \\
\hline 85 & 6,686 & 6,400 & 286 & $4.3 \%$ & 630 & 692 & -62 & $-9.8 \%$ \\
\hline 91 & 7,576 & 7,946 & -370 & $-4.9 \%$ & 246 & 330 & -84 & $-34.1 \%$ \\
\hline 92 & 7,637 & 6,473 & 1,164 & $15.2 \%$ & 302 & 282 & 20 & $6.6 \%$ \\
\hline 116 & 7,257 & 6,357 & 900 & $12.4 \%$ & 408.5 & 359.5 & 49 & $12.0 \%$ \\
\hline SMRS & 10,076 & 9,553 & 523 & $5.2 \%$ & 410 & 368 & 42 & $10.2 \%$ \\
\hline STKG & 10,095 & 8,971 & 1,124 & $11.1 \%$ & 969 & 570 & 399 & $41.2 \%$ \\
\hline Average & 8,308 & 7,738 & 570 & $6.9 \%$ & 544 & 491 & 53 & $9.7 \%$ \\
\hline
\end{tabular}

Table 5 and Table 6 show disaggregated energy use for space cooling and space heating/water heating, respectively, for the 24 houses. Average space cooling savings were $42 \%$, with a wide range from $-35 \%$ to $81 \%$. Many of the cases with increases in space cooling energy are expected to be explained by take-back or occupants taking advantage of increased comfort opportunities from better performing equipment and lower operating costs. Where energy use decreased in some homes, the regression analysis process demonstrated higher base temperatures for the postretrofit case, meaning that space cooling was required at higher average outdoor temperatures than in the pre-retrofit case. This is expected given the more stable interior temperatures afforded by a tighter, better-insulated building shell. 
Table 5. Air-Conditioning Electricity Savings From the HEUs

\begin{tabular}{|c|c|c|c|}
\hline \multirow[t]{2}{*}{$\begin{array}{c}\text { Reference } \\
\text { Household } \\
\text { Number }\end{array}$} & \multicolumn{3}{|c|}{$\begin{array}{c}\begin{array}{c}\text { Electricity Usage- } \\
\text { Normalized to TMY3 } \\
(\mathbf{k W h})\end{array} \\
\text { Air Conditioning }\end{array}$} \\
\hline & Pro & Post & Sgyinos \\
\hline 18 & 535 & 162 & $69.7 \%$ \\
\hline 19 & 1,970 & 737 & $62.6 \%$ \\
\hline 27 & 665 & 294 & $55.8 \%$ \\
\hline 31 & 4,190 & 1,170 & $72.1 \%$ \\
\hline 33 & 2,855 & 2,045 & $28.4 \%$ \\
\hline 37 & 743 & 853 & $-14.8 \%$ \\
\hline 40 & 1,443 & 701 & $51.4 \%$ \\
\hline 41 & 1,031 & 1,094 & $-6.1 \%$ \\
\hline 42 & 946 & 317 & $66.5 \%$ \\
\hline 44 & - & - & - \\
\hline 49 & 443 & 337 & $23.9 \%$ \\
\hline 52 & 259 & 88 & $66.0 \%$ \\
\hline 53 & - & - & - \\
\hline 54 & - & - & - \\
\hline 57 & 902 & 971 & $-7.6 \%$ \\
\hline 65 & 412 & 182 & $55.8 \%$ \\
\hline 73 & 1,446 & 843 & $41.7 \%$ \\
\hline 78 & 1,774 & 1,472 & $17.0 \%$ \\
\hline 85 & 786 & 500 & $36.4 \%$ \\
\hline 91 & 1,060 & 1,430 & $-34.9 \%$ \\
\hline 92 & 1,925 & 761 & $60.5 \%$ \\
\hline 116 & 1,417 & 517 & $63.5 \%$ \\
\hline SMRS & 1,001 & 478 & $52.2 \%$ \\
\hline STKG & 1,385 & 261 & $81.2 \%$ \\
\hline Average & 1,290 & 748 & $42.1 \%$ \\
\hline
\end{tabular}

In Table 6 average water heating savings (where water heaters were upgraded) were $31 \%$ with a range from $-42.7 \%$ to $65.1 \%$. Space heating average savings were $4.9 \%$ with a range from $-349 \%$ to $37.9 \%$. These phenomena of take-back apply equally to space heating and space cooling, and perhaps more so than typical within this sample based on the greater-thananticipated variability and lower-than-anticipated average savings. 
Table 6. Natural Gas Baseload and Space Heating Savings From the HEUs

\begin{tabular}{|c|c|c|c|c|c|c|}
\hline \multirow{3}{*}{$\begin{array}{c}\text { Reference } \\
\text { Household \# }\end{array}$} & \multicolumn{6}{|c|}{ Natural Gas Usage_-Normalized to TMY3 (therm) } \\
\hline & \multicolumn{3}{|c|}{ Baseload } & \multicolumn{3}{|c|}{ Space Heating } \\
\hline & Pre & Post & Savings & Pre & Post & Savings \\
\hline 18 & 231 & 218 & $5.6 \%$ & 62 & 119 & $-91.9 \%$ \\
\hline 19 & 166 & 226 & $-36.1 \%$ & 152 & 123 & $19.1 \%$ \\
\hline 27 & 217 & 207 & $4.6 \%$ & 484 & 394 & $18.6 \%$ \\
\hline 31 & 355 & 122 & $65.6 \%$ & 324 & 389 & $-20.1 \%$ \\
\hline 33 & 413 & 348 & $15.7 \%$ & 218 & 221 & $-1.4 \%$ \\
\hline 37 & 117 & 167 & $-42.7 \%$ & 33 & 148 & $-348.5 \%$ \\
\hline 40 & 438 & 175 & $60.0 \%$ & 362 & 291 & $19.6 \%$ \\
\hline 41 & 340 & 215 & $36.8 \%$ & 585 & 388 & $33.7 \%$ \\
\hline 42 & 224 & 200 & $10.7 \%$ & 264 & 164 & $37.9 \%$ \\
\hline 44 & 364 & 213 & $41.5 \%$ & 152 & 181 & $-19.1 \%$ \\
\hline 49 & 200 & 211 & $-5.5 \%$ & 388 & 426 & $-9.8 \%$ \\
\hline 52 & 211 & 229 & $-8.5 \%$ & 201 & 182 & $9.5 \%$ \\
\hline 53 & 303 & 247 & $18.5 \%$ & 486 & 375 & $22.8 \%$ \\
\hline 54 & 386 & 356 & $7.8 \%$ & 150 & 284 & $-89.3 \%$ \\
\hline 57 & 332 & 349 & $-5.1 \%$ & 228 & 160 & $29.8 \%$ \\
\hline 65 & 182 & 183 & $-0.5 \%$ & 519 & 409 & $21.2 \%$ \\
\hline 73 & 409 & 175 & $57.2 \%$ & 279 & 437 & $-56.6 \%$ \\
\hline 78 & 334 & 291 & $12.9 \%$ & 135 & 199 & $-47.4 \%$ \\
\hline 85 & 216 & 259 & $-19.9 \%$ & 414 & 433 & $-4.6 \%$ \\
\hline 91 & 94 & 152 & $-61.7 \%$ & 123 & 207 & $-68.3 \%$ \\
\hline 92 & 167 & 209 & $-25.1 \%$ & 114 & 94 & $17.5 \%$ \\
\hline 116 & 221 & 54 & $75.6 \%$ & 271 & 222 & $18.1 \%$ \\
\hline SMRS & 213 & 183 & $14.1 \%$ & 197 & 185 & $6.1 \%$ \\
\hline STKG & 272 & 95 & $65.1 \%$ & 697 & 475 & $31.9 \%$ \\
\hline Average & 299 & 206 & $31.1 \%^{1}$ & 285 & 271 & $4.9 \%$ \\
\hline
\end{tabular}

${ }^{1}$ Averages for baseload energy savings includes only those houses with water heater upgrades.

Figure 2 and Figure 3 show the distribution of electricity and gas savings, respectively, across the sample demonstrating that the distribution and variance are quite wide. Figure 4 and Figure 5 demonstrate the range of space cooling and space heating percent savings, based on the level of retrofit conducted. On the left sides of the graphs are houses that underwent air sealing and insulation upgrades only. Moving to the right, duct sealing, insulating, and HVAC upgrades are added. In theory, the percent savings would increase as deeper measures are incorporated. In reality, this trend is not observed and the range of savings is almost as wide across all the categories, indicating that occupancy changes and improved comfort are important factors in realized energy savings in HEUs. 


\section{Total Electricity Savings-Normalized to TMY3 (kWh)}

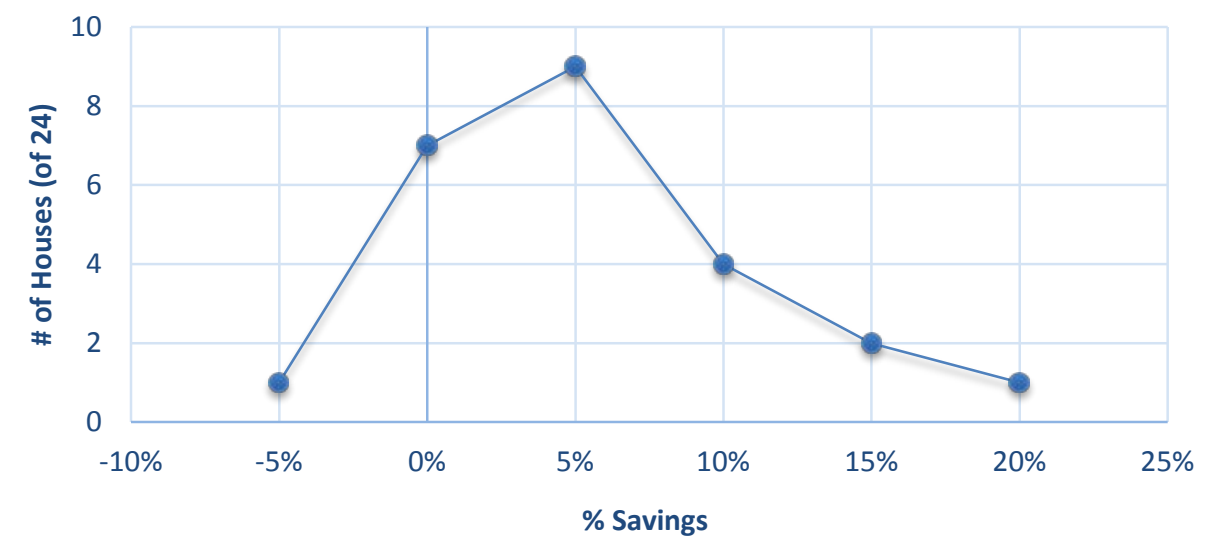

Figure 2. Distribution of electricity savings (\%)

\section{Total Gas Savings - Normalized to TMY3}

(therms)

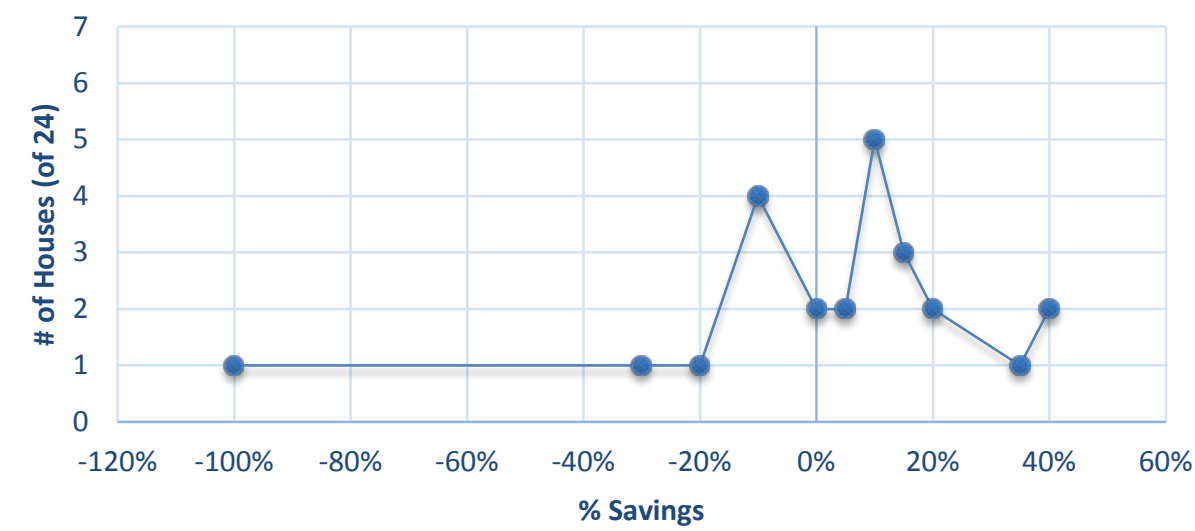

Figure 3. Distribution of gas savings (\%) 


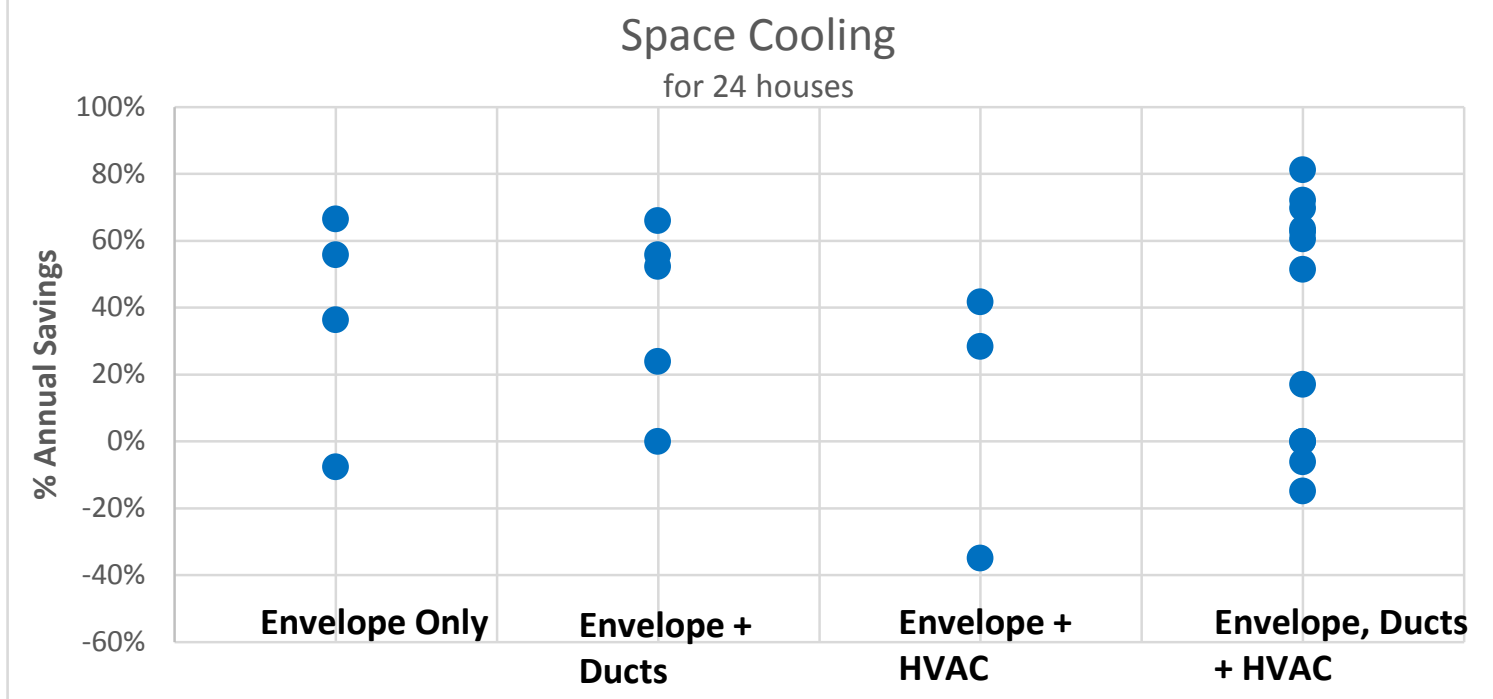

Figure 4. Space cooling savings as a function of efficiency measures implemented

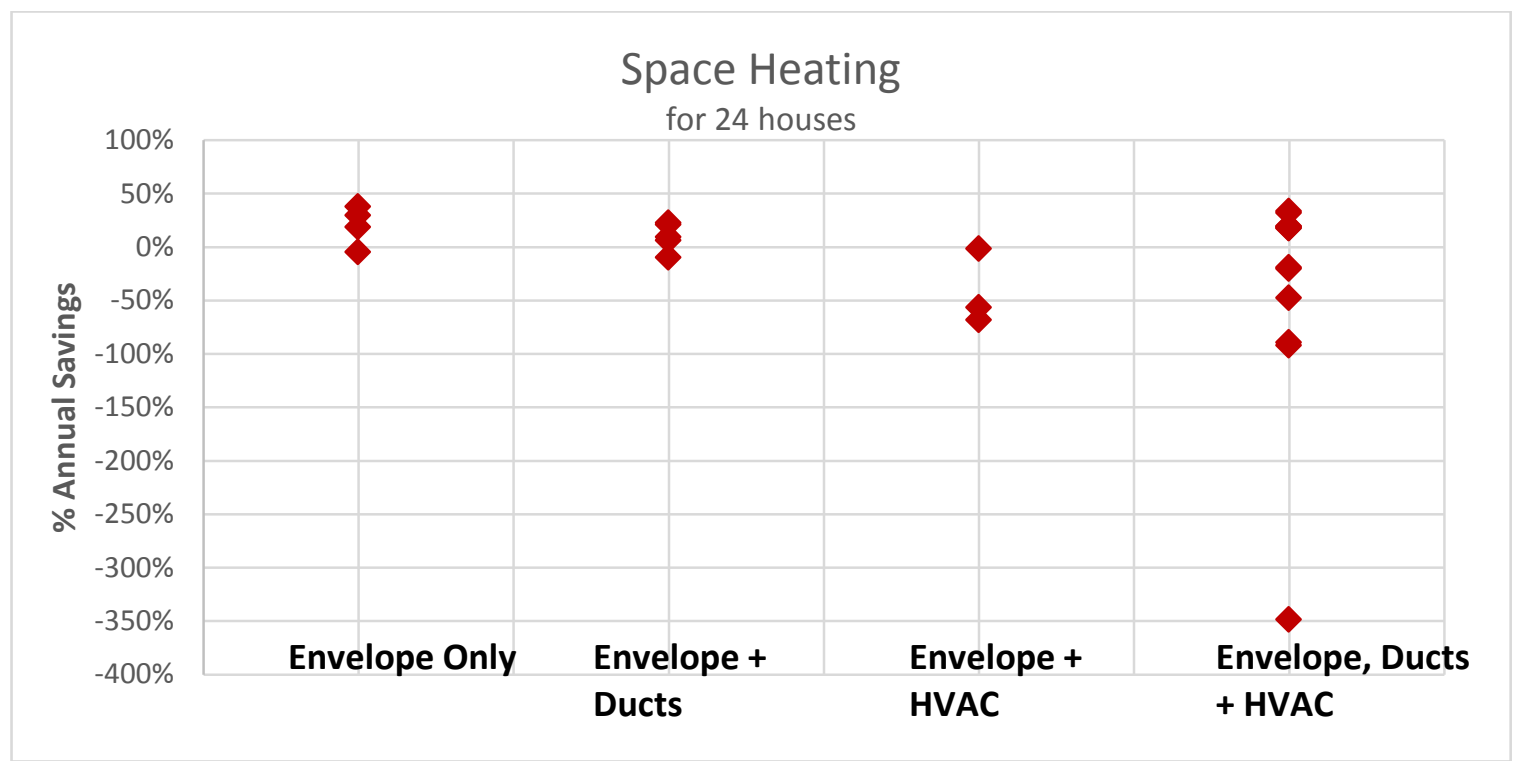

Figure 5. Space heating savings as a function of efficiency measures implemented

The success of this demonstration was exhibited with an average estimated total household electricity savings of $570 \mathrm{kWh}(6.9 \%)$ and total natural gas savings of 53 therms $(9.7 \%)$. Of the approximately 12.3 million California households (U.S. Census Bureau 2013), a market potential of 2 million single family homes built in California in the 1960s and 1970s are estimated (U.S. Census Bureau (2011), excluding homes without air conditioners, rental homes, recently remodeled homes, and low cooling energy users. Applying the savings estimated in this analysis, the technical potential of affecting these 2 million homes totals is $1,178 \mathrm{GWH} /$ year and $1.09 \times$ $10^{8}$ therms/year. 
The uncertainty of some results, reflected by the difficulty in identifying statistically valid relationships between energy use and weather for certain houses, as well as the variability of estimated savings, indicate that further work is warranted. All data in this study were collected in the Central Valley of California. A larger data set that covers multiple climate zones would improve statistical confidences. Monitoring pre- and post-retrofit thermostat set points and interior conditions and documenting major changes in occupancy pattern (e.g., a new baby) would improve the regression analysis and add valuable insight into how occupants may change habits after an energy retrofit. With the advent of communicating thermostats, obtaining thermostat set points may become easier. Another point of interest would be to evaluate indoor air quality pre- and post-retrofit. HEUs can improve indoor air quality and occupant health by reducing unintentional infiltration and better filtering outdoor air. 


\section{Conclusions}

The RYA program was designed using lessons learned from previous ARBI and DEG community retrofit program designs. The design consisted of:

- A limited scope of work that took advantage of energy-efficiency measures that typically produce the most energy savings and improved occupant comfort

- A limited number of contractors for participants to choose from, all offering the same price for the same retrofit

- Finding early adopters who can spur neighborhood-level growth through word-of-mouth and localized advertising techniques using community-based media for targeted messaging.

ARBI used lessons learned from other retrofit programs to design a program offering a very attractive price with appropriate messaging and community-based outreach. Despite launching RYA through a volunteer-run community organization in an affluent region of health- and energy-conscious homeowners, uptake was low. As in other programs throughout California, homeowners lacked awareness, had no sense of urgency, and still were mainly concerned about cost. Although this retrofit generally cost less than $\$ 4,000$ after incentives (varying with house size and condition), uptake was low. Even some of the volunteers working in the program who were very excited about having this retrofit done to their own homes decided not to participate because of cost, even though they understood they would receive a good price through the program.

Even in a community such as Davis that has highly educated homeowners who "talk the talk" of sustainability, the level of awareness about how much their home contributed to greenhouse gas emissions was extremely low. They also did not understand that their energy bills were higher than they needed to be. A nationwide awareness campaign is needed, including public service announcements, articles in newspapers, and more incentive programs to increase retrofit uptake.

In addition to a broad-based public awareness campaign, the financial playing field needs to be shifted so that the benefits of making a home more energy efficient are reflected in its value. One way to meet this critical requirement is included in the proposed bipartisan Sensible Accounting to Value Energy Act of 2013 [S.1106], which would include energy costs in the calculation of the cost of home ownership. By adding energy to the cost of principal, interest, taxes, and insurance, the standard calculation would become principal interest, taxes, insurance, and energy. If energy costs are demonstrated to be lower; e.g., through a lower Home Energy Rating System score, the ability to borrow principal would increase. In other words, presented with two houses comparable in all ways except energy consumption, a buyer could borrow more for the more efficient house. This would reverberate through the market, increasing the prices and appraised value for more efficient houses and creating an additional and stronger financial incentive for homeowners to complete HEUs. 


\section{References}

ASHRAE (2002). Guideline 14-2002 - Measurement of Energy and Demand Savings. Atlanta, GA: American Society of Heating, Refrigerating and Air-Conditioning Engineers.

Berman, M.; Smith, P.; Porse, E. (2014). Large Scale Residential Retrofit Program Task A.6.2 Final Report. Sacramento, CA: California Energy Commission.

California Energy Commission (2010). "Elements of Energy Upgrade California Program." http://www.energy.ca.gov/stimulus/documents/2010-0806_Elements_of_Energy_Upgrade_California_Financing_Program.pdf.

"Historical Census of Housing Tables: Units in Structure." (2011). U.S. Census Bureau. Accessed April 6, 2015: https://www.census.gov/hhes/www/housing/census/historic/units.html.

Kissock, J.K.; Haberl, J.S.; Claridge, D.E. (2004). RP-1050 -- Development of a Toolkit for Calculating Linear, Change-Point Linear and Multiple-Linear Inverse Building Energy Analysis Models. Atlanta, GA: American Society of Heating, Refrigerating and Air-Conditioning Engineers.

"Mission and Goals." (undated). Cool Davis. Accessed April 24, 2015: http://www.cooldavis.org/about/introduction/.

"QuickFacts Beta." (2013). U.S. Census Bureau. Accessed April 6, 2015: http://www.census.gov/quickfacts/dashboard/HSD410213/06,00.

“Energy Benefits Yolo Climate Compact. (2013). Group Energy. Accessed April 24, 2015 : http://www.mygroupenergy.com/group/yolo/. 
buildingamerica.gov

u.s. DEPARTMENT OF Energy Efficiency \& Nㅡㄹ R Renewable Energy 